\title{
CREATIVITY IN VIRTUAL TEAMS: BRIDGING THE GAP BETWEEN PROFESSIONAL WISDOM AND SCIENTIFIC INSIGHTS
}

\author{
Stéphanie BUISINE ${ }^{1 *}$, Jérôme GUEGAN ${ }^{2}$ \\ ${ }^{1}$ CESI Recherche: laboratoire LINEACT, 93 boulevard de la Seine, 92000 Nanterre, France \\ ${ }^{2}$ Paris Descartes University, Institut de Psychologie - LaPEA, 71 avenue Edouard Vaillant, \\ 92100 Boulogne Billancourt, France
}

Received 28 March 2018; accepted 05 April 2019

\begin{abstract}
Following the growing body of scientific literature dedicated to the effects of virtual tools and environments on creative processes, we were interested in examining how professional creativity facilitators perceive these technologies and the extent to which they might support their dissemination. To this end, we conducted a workshop with 19 professional facilitators in which they could experience creativity in a virtual environment. Their ratings of the potential impact of such tools on session facilitation, on sociocognitive processes of creativity and on group motivation were collected twice: before and after the virtual session. The results show that their perception of the potential benefits of virtual environments decreased after the test. They mentioned many limitations of the technology with regard to usual facilitation process. Moreover, their expert perception of the creative process sometimes appeared contradictory to scientific results obtained in the domain. We discuss these results and provide design perspectives to make virtual technologies more acceptable and usable for creativity facilitators, in order to allow more population to benefit from their positive effects on group creativity.
\end{abstract}

Keywords: adoption, creativity facilitation, innovation, tool, virtual environment.

\section{Introduction}

Creativity is the ability to produce work that is both novel and appropriate (Sternberg, 1999). It is the starting point to change the product range and offer new services in a context in which companies have to innovate and differentiate from their competitors. One of the most classical methods for structuring group creativity is the brainstorming (Osborn, 1953), which supports cognitive stimulation within the group (Leggett Dugosh \& Paulus, 2005; Nijstad, Stroebe, \& Lodewijkx, 2002) as well as social comparison (Leggett Dugosh \& Paulus, 2005; Michinov \& Primois, 2005). It was also observed that the presence of a facilitator (in particular an expert one), whose role is to ensure that the rules are respected, further enhances creativity (Kramer, Fleming, \& Mannis, 2001; Offner, Kramer, \& Winter, 1996;

\footnotetext{
${ }^{\star}$ Corresponding author. E-mail: sbuisine@cesi.fr
} 
Oxley, Dzindolet, \& Paulus, 1996; Paulus, Nakui, Putman, \& Brown, 2006). However, brainstorming situations also give rise to detrimental side effects, for example self-censorship of individuals (Williams, 2002) and social loafing among group members (Karau \& Williams, 1993; Serva \& Fuller, 1997). Besides, technological and organizational evolutions shape a new reality of teamwork and introduce new challenges to the brainstorming paradigm: in a globalized world, distributed collaborators have to work together and achieve high performance remotely (Gilson, Maynard, Jones Young, Vartiainen, \& Hakonen, 2015). In such a context, virtual environments seem to offer a promising tool to improve creativity and innovation: as elaborated below, their benefits stem from their capacity, first, to reveal individuals' creative potential and, second, to provide meaning to remote teamwork.

In virtual environments, users are represented by digital characters called avatars (Meadows, 2008). Beyond a mere graphical representation, avatars are projections of users or "tangible embodiment of their identity" (Yee, Bailenson, \& Ducheneaut, 2009) and can be used to experience multiple identities or highlight certain aspects of users' ideal self (Bessière, Seay, \& Kiesler, 2007). Thereby, avatars allow users to change their appearance, their social roles and their identity in a virtual world. A recent line of research has also shown that avatars influence users' behaviors congruently to their avatar's identity. This behavioral modulation was named Proteus effect (Yee \& Bailenson, 2007, 2009). On a theoretical viewpoint, this phenomenon could be explained through the seminal proposals of self-perception theory (Bem, 1972), according to which individuals explain their attitudes and internal states based on observation of external cues, just as an external observer would. This is why a change in self-representation may lead to a change in behavior. Moreover, in situations of anonymity and deindividuation (Postmes \& Spears, 1998) like in a virtual world, self-perception reliance on identity cues (and avatar's appearance) is likely to be enhanced (see Yee et al., 2009). Avatars, as support for virtual personal identity, may therefore influence the way in which individuals behave and/or perform.

The Proteus effect was consistently observed in several contexts: for example, attractive avatars lead to behave in a more intimate way in terms of self-disclosure and interpersonal distance (Yee \& Bailenson, 2007) and tall avatars lead to more confident behavior in a negotiation task (Yee \& Bailenson, 2007; Yee et al., 2009). It was also shown that the Proteus effect endures over time and affects subsequent offline behavior (Yee et al., 2009; Rosenberg, Baughman, \& Bailenson, 2013; Yoon \& Vargas, 2014). This means that the appearance of an avatar not only influences users' behavior in the virtual world, but also in the real world. Finally, a recent study (Guegan, Buisine, Mantelet, Maranzana, \& Segonds, 2016) showed that avatars looking like inventors increase the creative performance of engineers. This benefit also endured over time and participants allocated to inventor avatars continued to perform better in a subsequent face-to-face creativity task. The appearance of avatars may impact not only the creative performance in quantitative terms, but also the content of ideas. For example, practitioners embodying avatars representing future users generated more ideas related to user needs than practitioners using inventor avatars, and used significantly less technical terms in their ideas (Buisine, Guegan, Barré, Segonds, \& Aoussat, 2016). Avatars' appearance therefore appears likely to orient or improve creative processes. 
Regarding remote group creativity, early work has focused on electronic brainstorming systems in which participants generate ideas on computers networked together. This was shown to increase attention to others' ideas (Michinov, 2012) and improve idea production (Dennis \& Valacich, 1993; Kerr \& Murthy, 2004), in particular for large groups (DeRosa, Smith, \& Hantula, 2007; Paulus, Kohn, Arditti, \& Korde, 2013). However, electronic brainstorming provides low levels in perceived importance of group membership and sense of belonging (McKinlay, Procter, \& Dunnett, 1999). This analysis is consistent with early conceptions of computer-mediated communication (known as cues-filtered-out perspective, e.g., Kiesler, Siegel, \& McGuire, 1984; Sproull \& Kiesler, 1986), which considered that the reduction of social cues decreases social influence and remote collaborative work (Straus \& McGrath, 1994; also see Walther, Anderson, \& Park, 1994).

To overcome these limitations, virtual environments provide a means of introducing visually perceptible social cues on avatars and increase the motivation of participants to work together and combine their efforts. This could be explained in the social identity perspective (Tajfel \& Turner, 1979), according to which social identity is part of the self-concept linked to group membership: depending on the situation, individuals feel more or less part of a given social group. The social identity model of deindividuation effects (SIDE model) (Reicher, Spears, \& Postmes, 1995; Spears \& Lea, 1992, 1994) posits that social identity salience combined to anonymity increases identification to the group and group performance (see Tanis \& Postmes, 2008). Avatars can be used to introduce social identity cues (e.g., symbols of group membership, uniforms; Worchel, Rothgerber, Day, Hart, \& Butemeyer, 1998) and switch from personal to social identity in the virtual environment. Consistently, social identity cues on avatars' clothes during a virtual brainstorming task proved to increase both group identification and creative performance (Guegan et al., 2017b). More than - the mere representation of users, avatars also provide support to highlight what group members have in common, which may lead them to work together for the sake of a shared purpose.

Beyond the visual features of avatars, the whole virtual environment could also be used in order to improve creativity. Indeed, the environment - through the various cues involved in the situation - can also prime concepts and influence cognition and behavior. For example, Aaron C. Kay, S. Christian Wheeler, John Bargh, and Lee Ross (2004) have shown that the mere exposure to objects related to business (i.e., a briefcase, a boardroom, tables, a fountainpen) leads to the cognitive activation of competition and to less cooperative behavior. Jorge Peña and Kate Blackburn (2013) provided a first illustration of this kind of phenomenon in virtual environments. In this experiment, the authors manipulated the virtual context in which users interact (a library versus a coffee shop). The results showed that the virtual environment influenced behavior and mutual perception of interlocutors congruently to the primed concepts. Finally, recent studies showed that virtual scenes tailored to the representation of a place conducive to creativity increased creative performance in comparison to a more neutral virtual environment (Guegan, Nelson, \& Lubart, 2017a): when exposed to a bright, spacious and close to nature virtual environment, individuals produce more unique ideas and explore idea categories in greater depth than those exposed to a virtual meeting room. Another study showed that the content of the environment influenced the semantic categories of ideas produced (Nelson \& Guegan, 2019): according to the type of virtual envi- 
ronment (underwater vs. forest), individuals produce more ideas that are semantically-related to the concepts primed by the environment. As a consequence, the configuration of virtual environment - via the activation of concepts supported by contextual cues - could be used strategically to foster creativity.

\section{Research question}

This brief overview of the literature shows that virtual tools and environments may have a positive impact on creativity. However, we do not know the extent to which these findings are usable by creativity practitioners and match their intuitions as creativity experts. If they are not usable and intuitive, it may question short-term dissemination of research findings towards professional fields and more generally the applicability of research advances in virtual creativity. This issue may be particularly acute in the domain of sociocognitive impacts of virtual tools because this research area has emerged recently and may not have reached conventional wisdom yet. The present study aims to address the gap between scientific knowledge and professional expertise in the field of creativity facilitation. In particular, we evaluated the potential of virtual tools for creativity as perceived by creativity experts before and after having experienced such virtual tools. To do so, we used the virtual world Second Life, which was repeatedly used in creativity research (Ward \& Sonneborn, 2009; Guegan et al., 2016, 2017a, 2017b; Buisine et al., 2016; Bonnardel, Forens, \& Lefevre, 2016; Uribe Larach, \& Cabra, 2010; Ferguson, 2011). This "sandbox" virtual world proves readily accessible and includes straightforward programmable scripting and programming possibilities; it is also particularly cost effective due to the large amount of content already available (e.g. clothing, buildings, indoor and outdoor settings). Moreover, because of low system requirements, it seems widely usable for dissemination purposes and field deployment. We decided to make creativity experts experience a virtual session including avatar use and navigation in virtual environments. Avatars were given priority with regard to alternative virtual solutions (e.g., head-mounted display device) because of the consistent literature showing the potential influence of avatars' appearance on creativity: it seems therefore important that creativity expert be exposed to a virtual situation involving avatars. Moreover, we decided to have them navigate in several virtual scenes to show the potential inspirational value of virtual environment, as observed in previous research.

\section{Method}

19 professional creativity facilitators $(14 \mathrm{~F}, 5 \mathrm{M})$ aged 25 to $67(\mathrm{M}=46, \mathrm{SD}=12.2)$ with an average 9 -year professional experience $(\mathrm{SD}=11.4)$ participated in the workshop. They were mainly independent or internal consultants (from various companies) specialized in group facilitation for collaborative creativity sessions. They were all novices regarding the use of virtual tools, as assessed during the debriefing phase of the experiment.

Four virtual places in Second Life (Figure 1) were selected to provide an overview of the diversity of landscapes available: a lagoon environment with a view on the horizon and rising sun, giving a sense of immensity; a fantasy forest including e.g. giant mushrooms, 
cartoonish animals and fairytale houses; a luminous and colorful place in a nocturnal atmosphere; imaginary underwater ruins populated with ocean creatures. The aim was to help professional facilitators imagine how they could create specific atmospheres to shape their own creativity sessions.

Participants were provided with basic human avatars. They could communicate textually through Second Life built-in instant messaging system.

The participants attended a 45-min. plenary talk about the possibilities of virtual environments for supporting creativity sessions in groups. They were presented a state of the art of digital and virtual creativity tools, informed about classical components of virtual settings (avatars, environment, communication means) and given basic technical details regarding e.g. hardware, bandwidth requirements, 3D modeling, etc. However, we voluntarily did not provide them with information on the sociocognitive processes involved in such situations and the related theoretical background: our aim was to collect their spontaneous reactions and impressions, based on their experience as creativity coaches and uninfluenced by research findings.

After the plenary talk they were invited to fill in a questionnaire to measure their expectations about the impact of virtual devices on collective creativity sessions (e.g. impact on facilitation, satisfaction, motivation).

The participants were then installed in 3 computer rooms in groups of 6 to 7 participants in order to experience themselves teamwork in virtual environment (avatar manipulation,

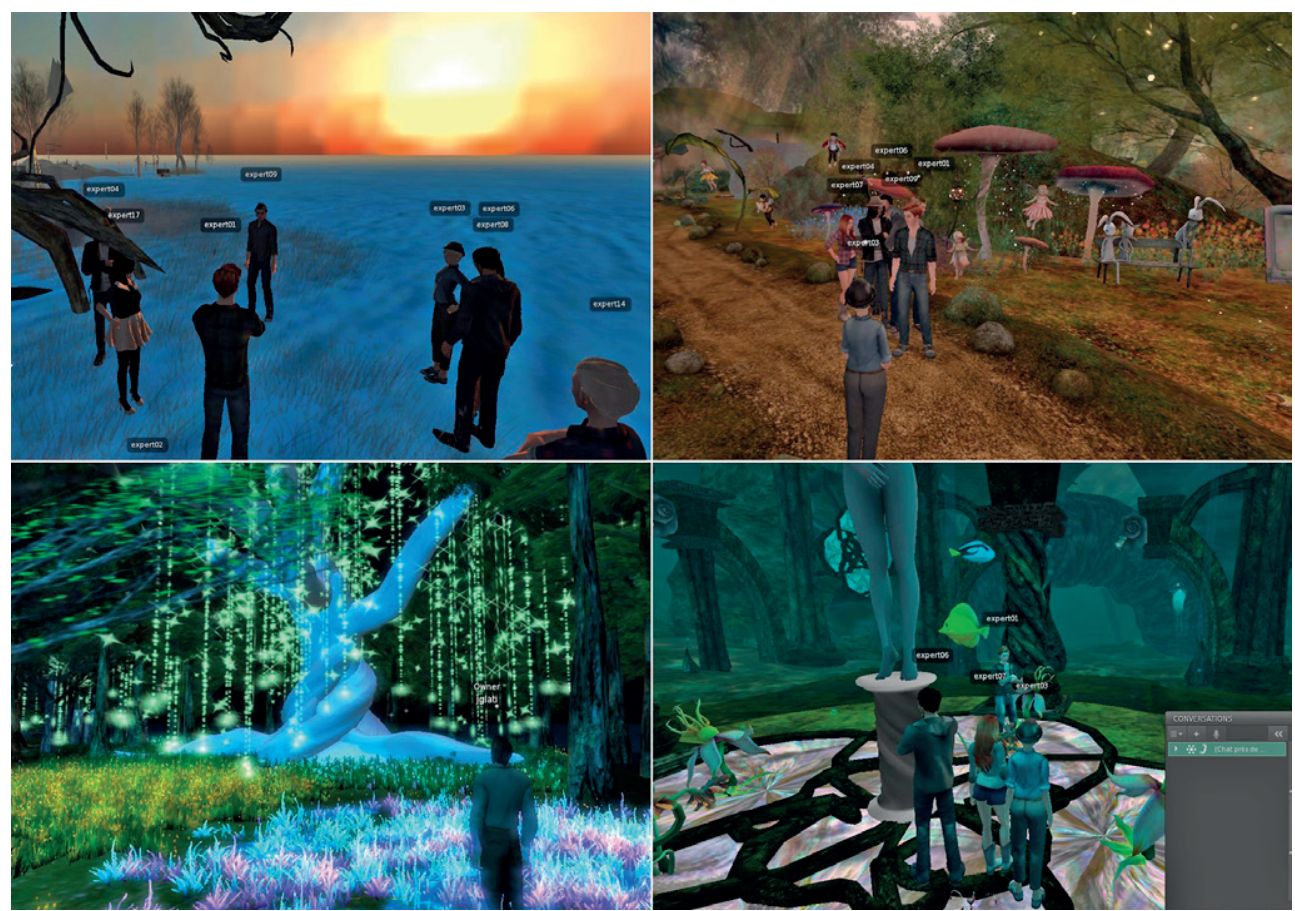

Figure 1. Screenshots of the virtual places used during the workshop and avatars of the participants (source: created by authors) 
navigation in the environment, interaction with team members, idea generation and discussion through instant messaging). They were instructed to visit the four target virtual places, explore them, discuss the pros and cons of each environment and imagine what kind of creative session they could conduct there with what kind of customer. They spent about 20 min. in each one of the four environments, which was pretested as a sufficient amount of time to explore a virtual area while thinking on its potential for applicative purposes. Furthermore, this limited duration allowed the participants to experience four different places and multiply sources of inspiration.

After this test they filled in the same questionnaire and rated a second time the potential impact of virtual tools on creativity. The whole experiment, including the initial plenary session, the practical workshop and the debriefing, lasted about 2.5 hours.

The questionnaire was made of 10 items distributed in two sections, each item being associated to a 1-to- 6 analogous scale. The items of the first section aimed to collect the perceived impact of the virtual tool on a creativity session and were submitted to a Principal Component Analysis. The Kaiser-Meyer-Olkin (KMO) test and Bartlett's test of sphericity $\left(\mathrm{KMO}=0.69, \chi^{2}=91.64, \mathrm{p}<0.001\right)$ verified the sampling adequacy for the analysis. The following components arose:

- Session facilitation $(\alpha=0.847)$ : In your opinion, is a virtual environment likely to support session animation? To support idea expression from anyone? To stimulate creative performance?;

- Sociocognitive processes $(\alpha=0.764)$ : In your opinion, is a virtual environment likely to increase identification to the group? To make participants feel more competent? To increase the level of attention to one another?;

- Motivation: In your opinion, is a virtual environment likely to decrease participants' motivation? (reversed item).

The second section aimed to assess, in absolute terms, the importance of three key factors onto the outcome of the creative session: According to your experience, would you say that the quality of ideas depends on the group? On the facilitator? On the environment?.

\section{Results}

Before the virtual session, ratings of the perceived value of virtual tools for supporting sociocognitive processes and motivation was not different from 3.5, which represents the middle of the scale $(\mathrm{t}(18)=-0.08, \mathrm{p}=0.93$ for sociocognitive processes, $\mathrm{t}(18)=0.64, \mathrm{p}=0.53$ for motivation). Ratings of the potential benefits on session facilitation were significantly higher than the middle on the scale $(\mathrm{t}(18)=5.37, \mathrm{p}<0.001)$. However, the before versus after comparison shows that perceived value of the tool for sociocognitive processes significantly decreases after the test $(\mathrm{t}(17)=3.504, \mathrm{p}=0.003$; Figure 2$)$. Ratings for session facilitation significantly decrease as well $(\mathrm{t}(17)=5.228, \mathrm{p}<0.001)$. Finally, the perceived value for motivating the participants does not significantly decrease $(\mathrm{t}(17)=0.669, \mathrm{p}=0.513)$.

The analysis of the importance of the 3 key factors (group versus facilitator versus environment) on creative outcome showed a main effect of the factor $(F(2,32)=8.657, p=0.001$, $\left.\eta^{2} \mathrm{p}=0.351\right)$. The group and the facilitator were rated as similarly important $(\mathrm{t}(18)=1.21$, 


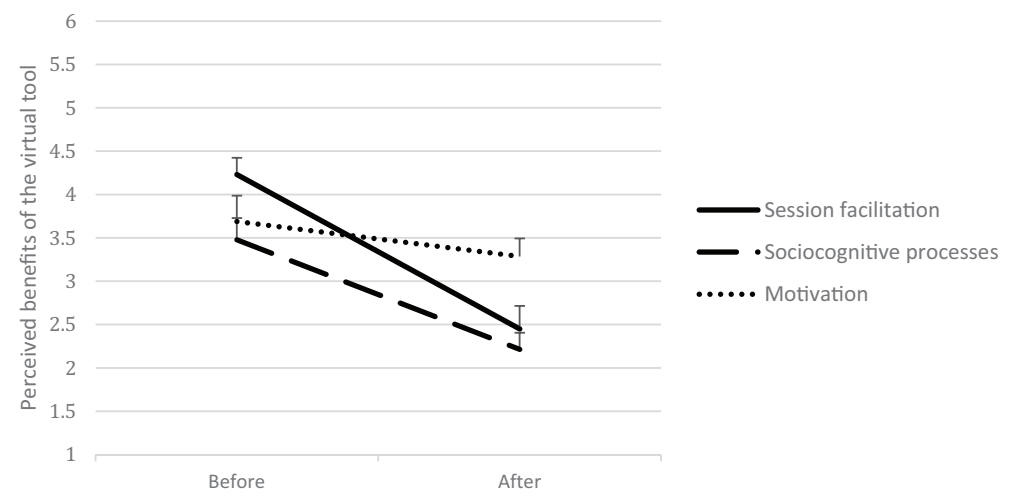

Figure 2. Benefits of the virtual environment on session facilitation, creative processes and motivation, as rated by experts before and after the test (source: created by authors)

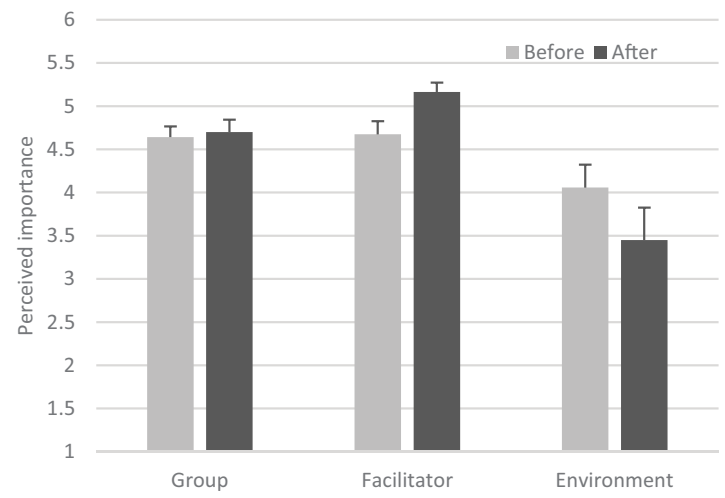

Figure 3. Importance of the group, the facilitator and the environment as rated by experts before and after the test (source: created by authors)

$\mathrm{p}=0.241)$ while the environment was judged as less important to the creative outcome $(t(18)=2.68, p=0.015$ for group versus environment; $t(18)=3.85, p=0.001$ for facilitator versus environment). We did not observe a main effect of the before/after variable $(\mathrm{F}(1,16)=$ $\left.0.129, \mathrm{p}=0.724, \eta^{2} \mathrm{p}=0.008\right)$ but the interaction effect proved significant $(\mathrm{F}(2,32)=7.404$, $\mathrm{p}=0.002, \eta^{2} \mathrm{p}=0.316$; Figure 3). Pairwise comparisons show that the importance of the facilitator, in experts' mind, significantly increased after the test $(t(18)=2.89, \mathrm{p}=0.011)$ while the importance of the environment tended to decrease after the test $(t(18)=1.96, p=0.067)$.

\section{Discussion}

The aim of this study was to expose expert creativity facilitators to virtual environment technologies in order to collect their viewpoint on field applicability and potential benefits for creativity facilitation. In particular, we were interested in examining whether their expert perception would match with scientific results in the domain. To do so, we collected facilitators' 
ratings of the potential impact of these technologies on session facilitation, creative processes and group motivation, before and after experiencing a workshop in a virtual environment.

The results show that the experts were not a priori reluctant to using virtual technologies, with initial ratings above or at the middle of the scale. However, experiencing the technology induced a decrease in experts' assessment of its potential for session facilitation and for supporting creative processes. The benefits of virtual environments for motivating creative groups was still recognized after testing the technology. Interestingly, this pattern of results is accompanied by an evolution in the relative weight of the three crucial factors in a creative session, namely the group, the facilitator, and the environment. After being exposed to the technology, the experts re-emphasized their key role as facilitators for the effectiveness of a creativity session. Conversely, the contribution of the environment tended to decrease in experts' mind.

During the post-experimental debriefing the expert participants stressed that the virtual modality was difficult to handle and questioned usual facilitation processes. For example, they expressed concern about the textual modality used for ideation: they felt it was a barrier to creativity and would have preferred to use the spoken modality in the virtual environment. Moreover, the storage of ideas in a linear chat was perceived as detrimental to awareness to others' ideas. Besides, facing a personal computer to generate ideas in a virtual environment was seen as an individualistic setting likely to break or hinder social relations and group cohesion. Finally, the expert participants questioned the likelihood that the elements present in the virtual scenes would influence the creative production. They nonetheless found that performing creativity session in a context of anonymity may disinhibit group members and enhance fluency. They also considered that virtual tools could be useful for remote collaborative sessions and creativity in large groups, but this would require the design of a new facilitation process adapted to the virtual modality. All in all, the decrease in perceived value of virtual tools after the test could be partly interpreted as some reluctance to change, considering that using such new tool would require significant changes in their professional practices, even if some of them expressed enthusiasm and said it opened new promising perspectives.

Regarding concrete facilitation procedure and effectiveness of a creativity session, one might consider that professional facilitators have an expert view and may provide accurate insights. In this respect, scientific literature in creativity could benefit from their empirical knowledge gained in real-world projects and contexts, to complement the results obtained in laboratory settings. However, they only hold an intuitive perception of the sociocognitive processes involved in group creativity, and that were documented through experimental research. The gap may even be larger because the research in creativity has identified some counterintuitive or paradoxical effects. More specifically, their insight to promote the spoken modality was ruled out by numerous experimental studies, which consistently showed that spoken brainstorming leads to production blocking and that the written modality is more effective for idea generation in group (Nijstad, Stroebe, \& Lodewijkx, 2003; Michinov \& Primois, 2005; Diehl \& Stroebe, 1987). Their perception that the virtual environment is conducive to social loss is congruent with early theories of computer-mediated communication, which were late invalidated by research showing that paradoxically such settings are prone to group identification, collaborative performance and group satisfaction (Tanis \& Postmes, 
2008; Guegan et al., 2017b; Peña et al., 2017). The whole body of research related to the SIDE model (Reicher et al., 1995; Spears \& Lea, 1992, 1994) tends to contradict our experts' intuitive view. Finally, their view that the environment has little influence on creativity process is contrary to research results regarding the influence of contextual cues through behavioral priming and/or semantic priming (e.g., G. M. Fitzsimons, Chartrand, \& G. J. Fitzsimons, 2008; Rietzschel, Nijstad, \& Stroebe, 2007).

\section{Concluding remarks}

This study highlighted current limitations of virtual tools, making short-term dissemination in professional fields difficult. We hereafter provide some design ideas for virtual creativity environments that may foster their acceptability by professional facilitators. Regarding the modality for interacting in the virtual environment, it is of utmost importance to keep the written channel for idea generation, but it may be possible to allow the facilitator to speak in order to optimize his/her interventions as well as to grant him/her a special status in the session. Furthermore, the storage of ideas in the textual interface could be improved for the facilitator and the participants to be able to rearrange and cluster them. The facilitator could also be provided with a board or a special space in the environment to display information or instructions independently from the idea generation space. Such features may help facilitators appropriate virtual technologies to make the whole group benefit from the associated sociocognitive levers.

Virtual environment will not replace current facilitation practices in the short or the long term but should be seen as a new tool available when necessary or relevant, in conjunction with more traditional tools. For example, virtual environments can be used for remote creativity sessions, but also for creating new dynamics, addressing problems with a new viewpoint and/or changing routines and habits among regular coworkers (e.g. hierarchical asymmetry, interpersonal relations, leadership).

Overall, this study shows that scientific research on creativity provides findings that could not always be inferred from professional intuition based on empirical expertise and regular practice. In that sense, these two types of knowledge appear as relevant and complementary but would benefit from interacting more closely with each other.

\section{References}

Bem, D. J. (1972). Self-perception theory. Advances in Experimental Social Psychology, 6, 1-62. https://doi.org/10.1016/S0065-2601(08)60024-6

Bessière, K., Seay, A. F., \& Kiesler, S. (2007). The Ideal Elf: identity exploration in world of Warcraft. CyberPsychology and Behavior, 10(4), 530-535. https://doi.org/10.1089/cpb.2007.9994

Bonnardel, N., Forens, M., \& Lefevre, M. (2016). Enhancing collective creative design: an exploratory study on the influence of static and dynamic personas in a virtual environment. The Design Journal, 19(2), 221-235. https://doi.org/10.1080/14606925.2016.1129145

Buisine, S., Guegan, J., Barré, J., Segonds, F., \& Aoussat, A. (2016). Using avatars to Tailor Ideation process to innovation strategy. Cognition, Technology \& Work, 18(3), 583-594.

https://doi.org/10.1007/s10111-016-0378-y 
Dennis, A. R., \& Valacich, J. S. (1993). Computer brainstorms: more heads are better than one. Journal of Applied Psychology, 78(4), 531-537. https://doi.org/10.1037/0021-9010.78.4.531

DeRosa, D. M., Smith, C. L., \& Hantula, D. A. (2007). The medium matters: mining the long-promised merit of group interaction in creative idea generation tasks in a meta-analysis of the electronic group brainstorming literature. Computers in Human Behavior, 23(3), 1549-1581. https://doi.org/10.1016/j.chb.2005.07.003

Diehl, M., \& Stroebe, W. (1987). Productivity loss in brainstorming groups: toward the solution of a riddle. Journal of Personality and Social Psychology, 53(3), 497-509. https://doi.org/10.1037/0022-3514.53.3.497

Ferguson, R. (2011). Meaningful learning and creativity in virtual worlds. Thinking Skills and Creativity, 6, 169-178. https://doi.org/10.1016/j.tsc.2011.07.001

Fitzsimons, G. M., Chartrand, T. L., \& Fitzsimons, G. J. (2008). Automatic effects of brand exposure on motivated behavior: how Apple makes you "Think Different". Journal of Consumer Research, 35, 21-35. https://doi.org/10.1086/527269

Gilson, L. L., Maynard, M. T., Jones Young, N. C., Vartiainen, M., \& Hakonen, M. (2015). Virtual teams research: 10 years, 10 themes, and 10 opportunities. Journal of Management, 41(5), 1313-1337. https://doi.org/10.1177/0149206314559946

Guegan, J., Buisine, S., Mantelet, F., Maranzana, N., \& Segonds, F. (2016). Avatar-mediated creativity: when embodying inventors makes engineers more creative. Computers in Human Behavior, 61, 165-175. https://doi.org/10.1016/j.chb.2016.03.024

Guegan, J., Nelson, J., \& Lubart, T. (2017a). The relationship between contextual cues in virtual environments and creative processes. Cyberpsychology, Behavior, and Social Networking, 20(3), 202-206. https://doi.org/10.1089/cyber.2016.0503

Guegan, J., Segonds, F., Barré, J., Maranzana, N., Mantelet, F., \& Buisine, S. (2017b). Social identity cues to improve creativity and identification in face-to-face and virtual groups. Computers in Human Behavior, 77, 140-147. https://doi.org/10.1016/j.chb.2017.08.043

Karau, S. J., \& Williams, K. D. (1993). Social loafing: a meta-analytic review and theoretical integration. Journal of Personality and Social Psychology, 65(4), 681-706.

https://doi.org/10.1037/0022-3514.65.4.681

Kay, A. C., Wheeler, S. Ch., Bargh, J. A., \& Ross, L. (2004). Material priming: the influence of mundane physical objects on situational construal and competitive behavioral choice. Organizational Behavior and Human Decision Processes, 95(1), 83-96. https://doi.org/10.1016/j.obhdp.2004.06.003

Kerr, D. S., \& Murthy, U. S. (2004). Divergent and convergent idea generation in teams: a comparison of computer-mediated and face-to-face communication. Group Decision and Negotiation, 13(4), 381-399. https://doi.org/10.1023/B:GRUP.0000042960.38411.52

Kiesler, S., Siegel, J., \& McGuire, T. W. (1984). Social psychological aspects of computer-mediated communication. American Psychologist, 39(10), 1123-1134.

https://doi.org/10.1037/0003-066X.39.10.1123

Kramer, Th. J., Fleming, G. P., \& Mannis, S. M. (2001). Improving face-to-face brainstorming through modeling and facilitation. Small Group Research, 32(5), 533-557. https://doi.org/10.1177/104649640103200502

Leggett Dugosh, K., \& Paulus, P. B. (2005). Cognitive and social comparison processes in brainstorming. Journal of Experimental Social Psychology, 41(3), 313-320. https://doi.org/10.1016/j.jesp.2004.05.009

McKinlay, A., Procter, R., \& Dunnett, A. (1999, 14-17 November). An investigation of social loafing and social compensation in computer-supported cooperative work. Proceedings of the International ACM SIGGROUP Conference on Supporting Group Work (pp. 249-257). International ACM SIGGROUP Conference on Supporting Group Work 1999. Phoenix, Arizona, USA.

https://doi.org/10.1145/320297.320327 
Meadows, M. S. (2008). I, Avatar: the culture and consequences of having a second life. Project: Voices That Matter. Morgan, B. (Project Ed.). Berkley: New Riders.

Michinov, N. (2012). Is electronic brainstorming or brainwriting the best way to improve creative performance in groups? An overlooked comparison of two idea-generation techniques. Journal of Applied Social Psychology, 42(S1), E222-E243. https://doi.org/10.1111/j.1559-1816.2012.01024.x

Michinov, N., \& Primois, C. (2005). Improving productivity and creativity in online groups through social comparison process: new evidence for asynchronous electronic brainstorming. Computers in Human Behavior, 21(1), 11-28. https://doi.org/10.1016/j.chb.2004.02.004

Nelson, J., \& Guegan, J. (2019). "I'd like to be under the sea": contextual cues in virtual environments influence the orientation of idea generation. Computers in Human Behavior, 90, 93-102. https://doi.org/10.1016/j.chb.2018.08.001

Nijstad, B. A., Stroebe, W., \& Lodewijkx, H. F. M. (2002). Cognitive stimulation and interference in groups: exposure effects in an idea generation task. Journal of Experimental Social Psychology, 38(6), 535-544. https://doi.org/10.1016/S0022-1031(02)00500-0

Nijstad, B. A., Stroebe, W., \& Lodewijkx, H. F. M. (2003). Production blocking and idea generation: does blocking interfere with cognitive processes? Journal of Experimental Social Psychology, 39(6), 531-548. https://doi.org/10.1016/S0022-1031(03)00040-4

Offner, A. K., Kramer, Th. J., \& Winter, J. P. (1996). The effects of facilitation, recording, and pauses on group brainstorming. Small Group Research, 27(2), 283-298. https://doi.org/10.1177/1046496496272005

Osborn, A. F. (1953). Applied imagination: principles and procedures of creative problem-solving. New York: Charles Scribner's Sons.

Oxley, N. L., Dzindolet, M. T., \& Paulus, P. B. (1996). The effects of facilitators on the performance of brainstorming groups. Journal of Social Behavior \& Personality, 11(4), 633-646.

Paulus, P. B., Kohn, N. W., Arditti, L. E., \& Korde, R. M. (2013). Understanding the group size effect in electronic brainstorming. Small Group Research, 44(3), 332-352. https://doi.org/10.1177/1046496413479674

Paulus, P. B., Nakui, T., Putman, V. L., \& Brown, V. R. (2006). Effects of task instructions and brief breaks on brainstorming. Group Dynamics: Theory, Research, and Practice, 10(3), 206-219. https://doi.org/10.1037/1089-2699.10.3.206

Peña, J., \& Blackburn, K. (2013). The priming effects of virtual environments on interpersonal perceptions and behaviors. Journal of Communication, 63(4), 703-720. https://doi.org/10.1111/jcom.12043

Peña, J., Ghaznavi, J., Brody, N., Prada, R., Martinho, C., Santos, P. A., Damas, H., \& Dimas, J. (2017). Effects of human $v s$. computer-controlled characters and social identity cues on enjoyment: mediation effects of presence, similarity, and group identification. Journal of Media Psychology: Theories, Methods, and Applications. Retrieved from https://www.academia.edu/33040977/Effects_of_Human_vs._Computer-_Controlled_Characters_and_Social_Identity_Cues_on_Enjoyment_Mediation_Effects_of_Presence_Similarity_and_Group_Identification

Postmes, T., \& Spears, R. (1998). Deindividuation and anti-normative behavior: a meta-analysis. Psychological Bulletin, 123(3), 238-259. https://doi.org/10.1037/0033-2909.123.3.238

Reicher, S. D., Spears, R., \& Postmes, T. (1995). A social identity model of deindividuation phenomena. European Review of Social Psychology, 6(1), 161-198. https://doi.org/10.1080/14792779443000049

Rietzschel, E. F., Nijstad, B. A., \& Stroebe, W. (2007). Relative accessibility of domain knowledge and creativity: the effects of knowledge activation on the quantity and originality of generated ideas. Journal of Experimental Social Psychology, 43(6), 933-946. https://doi.org/10.1016/j.jesp.2006.10.014

Rosenberg, R. S., Baughman, Sh. L., \& Bailenson, J. N. (2013). Virtual superheroes: using superpowers in virtual reality to encourage prosocial behavior. PloS ONE, 8(1), 1-9.

https://doi.org/10.1371/journal.pone.0055003 
Serva, M. A., \& Fuller, M. A. (1997, 3-5 April). Preventing social loafing in the collaborative technology classroom. Proceedings of the 1997 ACM SIGCPR Conference on Computer Personnel Research (pp. 84-86). ACM SIGCPR Conference on Computer Personnel Research 1997. San Francisco, California, USA. https://doi.org/10.1145/268820.268870

Spears, R., \& Lea, M. (1994). Panacea or panopticon? The hidden power in computer-mediated communication. Communication Research, 21(4), 427-459.

Spears, R., \& Lea, M. (1992). Social influence and the influence of the "social" in computer-mediated communication. In M. Lea (Ed.), Contexts of computer-mediated communication (pp. 30-65). London: Harvester-Wheatsheaf. https://doi.org/10.1177/009365094021004001

Sproull, L., \& Kiesler, S. (1986). Reducing social context cues: electronic mail in organizational communication. Management Science, 32(11), 1492-1512. https://doi.org/10.1287/mnsc.32.11.1492

Sternberg, R. J. (Ed.). (1999). Handbook of creativity. Cambridge: Cambridge University Press.

Straus, S. G., \& McGrath, J. E. (1994). Does the medium matter? The interaction of task type and technology on group performance and member reactions. Journal of Applied Psychology, 79(1), 87-97. https://doi.org/10.1037/0021-9010.79.1.87

Tajfel, H., \& Turner, J. (1979). An integrative theory of intergroup conflict. In W. G. Austin \& S. Worchel (Eds.), The social psychology of intergroup relation (pp. 33-47). Monterey, CA: Brooks/Cole.

Tanis, M., \& Postmes, T. (2008). Cues to identity in online dyads: effects of interpersonal versus intragroup perceptions on performance. Group Dynamics: Theory, Research, and Practice, 12(2), 96-111. https://doi.org/10.1037/1089-2699.12.2.96

Uribe Larach, D., \& Cabra, J. F. (2010). Creative problem solving in second life: an action research study. Creativity and Innovation Management, 19(2), 167-179. https://doi.org/10.1111/j.1467-8691.2010.00550.x

Walther, J. B., Anderson, J. F., \& Park, D. W. (1994). Interpersonal effects in computer-mediated interaction: a meta-analysis of social and antisocial communication. Communication Research, 21(4), 460-487. https://doi.org/10.1177/009365094021004002

Ward, Th. B., \& Sonneborn, M. S. (2009). Creative expression in virtual worlds: imitation, imagination, and individualized collaboration. Psychology of Aesthetics, Creativity, and the Arts, 3(4), 211-221. https://doi.org/10.1037/a0016297

Williams, S. D. (2002). Self-esteem and the self-censorship of creative ideas. Personnel Review, 31(4), 495-503. https://doi.org/10.1108/00483480210430391

Worchel, S., Rothgerber, H., Day, E. A., Hart, D., \& Butemeyer, J. (1998). Social identity and individual productivity within groups. British Journal of Social Psychology, 37(4), 389-413. https://doi.org/10.1111/j.2044-8309.1998.tb01181.x

Yee, N., \& Bailenson, J. N. (2009). The difference between being and seeing: the relative contribution of self-perception and priming to behavioral changes via digital self-representation. Media Psychology, 12(2), 195-209. https://doi.org/10.1080/15213260902849943

Yee, N., \& Bailenson, J. (2007). The proteus effect: the effect of transformed self-representation on behavior. Human Communication Research, 33(3), 271-290. https://doi.org/10.1111/j.1468-2958.2007.00299.x

Yee, N., Bailenson, J. N., \& Ducheneaut, N. (2009). The proteus effect: implications of transformed digital self-representation on online and offline behavior. Communication Research, 36(2), 285-312. https://doi.org/10.1177/0093650208330254

Yoon, G., \& Vargas, P. T. (2014). Know thy avatar: the unintended effect of virtual-self representation on behavior. Psychological Science, 25(4), 1043-1045. https://doi.org/10.1177/0956797613519271 


\title{
KÜRYBIŠKUMAS VIRTUALIOSIOSE KOMANDOSE: ATOTRŪKIO IVEIKIMAS TARP PROFESINĖS IŠMINTIES IR MOKSLINIŲ İŽVALGŲ
}

\author{
Stéphanie BUISINE, Jérôme GUEGAN
}

\section{Santrauka}

Remiantis didejjančiu mokslinès literatūros, skirtos virtualių priemonių ir aplinkos poveikiui kūrybiniuose procesuose, kiekiu, nagrinèjama, kaip profesinès išminties fasilitatoriai suvokia šias technologijas ir mastą, kuriuo jie galètų sustiprinti savo veiklos sklaidą. Šiuo tikslu surengtas seminaras, kuriame dalyvavo 19 profesionalių fasilitatorių. Seminare jie turèjo galimybę igyti kūrybiškumo patirties virtualiojoje aplinkoje. Tokių priemonių galimo poveikio vertinimai sesijos palengvinimo, kūrybiškumo sociokognityvinių procesų ir grupès motyvacijos aspektais buvo atlikti du kartus - prieš ir po virtualiosios sesijos. Rezultatai rodo, kad jų virtualiosios aplinkos teikiamos galimos naudos suvokimas sumenko po atlikto bandymo. Jie paminejo daugybę technologijų keliamų apribojimų, susijusių su ịprastine fasilitacija. Be to, jų ekspertinis kūrybiškumo proceso suvokimas kartais atrode prieštaraujantis šioje srityje gautiems moksliniams rezultatams. Rezultatai aptarti ir pateiktos su projektavimu susijusios perspektyvos, kad virtualiosios technologijos taptų priimtinesnès ir naudojamos kūrybiškumo fasilitatorių ir kad didesnè populiacijos dalis gautų naudos iš jų pozityvaus poveikio grupès kūrybiškumui.

Reikšminiai žodžiai: ịsisavinimas, kūrybiškumo fasilitacija, inovacija, priemonė, virtualioji aplinka. 